\title{
Psycho Education Program for Prevention of Test Anxiety on 8th Grade Students to Reduce Anxiety and Indecisiveness
}

\author{
Mehmet Kaya \\ Research Assistant, Bingol University, \\ Psychology Department, \\ uzm.psk. dan@gmail.com Tlf: 00905302758223
}

\begin{abstract}
This study aims to investigate the effect of psycho-education program on reducing the test anxiety and personal indecisiveness. The study was carried out with a group of ten 8th class volunteer students whose test anxiety scores were high. The test anxiety which is one of the study's variables was tested with Test Anxiety Inventory (TAl) that is adapted to Turkish by Öner (1990). Besides, Personal Indecisiveness Scale (PIS) that was developed by Bacanlı (2000) was applied. The Psyco-education Program to the group was applied in 7 sessions. The study is semi-experimental and depended on pretest, last-test model. Wilcoxon's signed rank test was used to analyze data and . 05 significancy level was used as criteria in interpreting results. As a result, it was observed that psycho-education program to 8th class students is effective on reducing: the test anxiety scores of students; personal indecisiveness; (implicitly) social anxiety and increasing self-reliance.
\end{abstract}

Keywords: Test Anxiety, Anxiety, Psycho-educational Groups

\section{Introduction}

Education is a process of making desired changes intentionally in one's life through experience (Ertürk, 1986). To define education in its widest meaning, it is "raising human" (Fidan, 2012; Totan \& Yavuz, 2009). This raising process happens in two ways as formal and informal.

Formal education is conducted by a teacher in a special area from the begining to the end of the process. It is carried on within a pre-determined program. Informal education is a haphazard process that is not intentional and planned and takes place in the life. The person is affected by the environment in which he or she lives, interacts, and learns (Fidan, 2012). Therefore, results of the formal education is always desired, while it is hard to say the same for the informal education. For example, incidents like cheating, slanging and smoking happen haphazardly and are undesired aspects of the informal education (Fidan, 2012; Senemoğlu, 2009; Şahin, 2007; Totan \& Yavuz, 2009).

Teaching is giving pre-determined targets to a person in the responsibility of teachers (Senemoğlu, 2009; Totan \& Yavuz, 2009). These two concepts brings us to another important concept: learning. Because, the main purpose of education and teaching is enabling learning. Therefore, learning can be explained as the product of person's life, permanent changes in behaviour and the process of gaining new behaviours (Senemoğlu, 2009; Şahin, 2007; Totan \& Yavuz, 2009). Finally, guidance is a process that includes helps of experts in order to make people happy and productive and to reach required qualities (Erkan, 2006).

To understand the test anxiety, these concepts must be understood well. Because, test anxiety has many dimensions (Erözkan, 2009; Totan \& Yavuz, 2009). Those dimensions are increased level of knowledge, educational system, life periods, attitude of teacher, expectation of family and society, socio-economical level etc. For example, evaluation process which is the last period of teaching process may lead many problems (Totan \& Yavuz, 2009). Also, increased level of knowledge and its spread make it difficult for adolescents who are in the education-teaching process to adapt different situations (Çapulcuoğlu \& Gündüz, 2013).

As the formal part of education is considered, it is known that attitude of teacher towards lecture, towards student and student's attitude towards lecture proportionately has effect on increase or decrease of test anxiety (Şahin, Günay \& Batı 2006). To give example from informal part, academic success of student - it was expressed by many researchers (Bacanlı 
\& Sürücü, 2006; Erözkan, 2004; Totan \& Yavuz, 2009) that test anxiety is meaningful to predict success- is afeccted by students' family, environment he lives in and from society life. All those factors have press on student (Adana \& Kaya, 2004; Erözkan, 2009; Grzesiak-Feldman, 2013; Totan \& Yavuz, 2009; Yıldırım, 2000). Actually, the press is not only on student but also on his or her family. That is, because of cost of living and limited job opportunities, academic success is important for student and his or her family and concerns student as well as society life.

Development of a society depends on raising academically successful and qualified people. In this point of view, investments that are made in education actually are made in development of society in long term (Yıldırım, 2000). It is known that, education is a multi variable, theoretical and experimental science. Therefore, educational settings must be controlled consistently and deficiencies be evaluated and removed in order to reach targets (Sönmez, 1987). Only in this way academically successful and qualified people can be raised. However, an important number of academically successful students can not prove their success because of the test anxiety (Baltaş \& Baltaş, 2002). Considering that, exams are important evaluation tools in Turkey's education system (Şahin, Günay \& Batı 2006; Totan\& Yavuz, 2009) the situation can be understood better -and it must be because of this reason that test anxiety is one of the most mentioned and researced topics (Carrol \& Fisher, 2013; Sparfeld, Rost, Baumestier \& Christ, 2013; Yöndem, 2011). There are researches in literature related to understanding anxiety before exams and coping with the anxiety related problems (Lowe ve ark. , 2008; Meijer, 2001).

Many researchers (Kuzgun, 1986; Bacanlı \& Sürücü, 2006; Büyükgöze-Kavas, 2012; Fuqua, Newman \& Seaworth, 1988; Kimes ve Troth, 1974) mentioned that there is a close relation between anxiety and indecisiveness / decision making skills. It is known that decision making behaviour is confronted in every part of life (Çakır, 2004; Çolakkadıoğlu \& Güçray, 2012). The situation of "being at peace with himself/herself" which is a criteria of being a healthy person is shaped with decisions made by the person (Çakır, 2004; Çolakkadıoğlu \& Güçray, 2007). Feelings before and after decision are not always positive and may cause other problems. A right decision made by person saves him or her from complex and worry so that it facilitates the situation of being happy. Making a right decision is possible by reaching right information and evaluating reached information (Çakır, 2004).

Test anxiety can be defined as perceived threat to physiological, cognitive and emotional condition that a person experiences in situation of being evaluated during his or her academic life (Bruman-Fulks, Berman, Martin, Marsic \& Haris, 2009; Carrol \& Fisher, 2013; Erözkan, 2004; Erözkan, 2009; Piji Küçük, 2010; Totan \& Yavuz, 2009). Researchers mentioned two dimensions of this threat: worry and emotionality (Sparfeld, Rost, Baumestier \& Christ, 2013). Worries are cognitive dimensions of anxiety and are a person s negative judgements about himself or herself. Emotionality is physiological dimension of anxiety. It includes sweating of hands, fast heartbeating, feeling cold and turning red (Erözkan, 2009; Piji Küçük, 2010; Totan \& Yavuz, 2009 Yöndem, 2011; Yurdabakan, 2012). Almost everybody feels a small quantity of anxiety, but this is a desired anxiety and leads to success (Piji Küçük, 2010; Yöndem, 2011). On the other hand, undesired test anxiety is perceiving the test as life and death issue because of reasons such as; thougt of not finishing the test in time, fear of failure, thought of not comprehending the test, feeling guilty resulted from thought of not studied well, thought of desperating his or her relatives, hyper activity and nausea (Piji Küçük, 2010; Şahin, Günay \& Batı 2006). Since this situation is perceived as the most serious barrier to success (Adana \& Kaya, 2004), it leads to psychosomatic ilnesses, a deppressive personality (Bruman-Fulks, Berman, Martin, Marsic\& Haris, 2009; Erözkan, 2009; Piji Küçük, 2010; Totan \& Yavuz, 2009) and negative personal specialties like low self-esteem and neurotism (Bacanlı \& Sürücü, 2006).

In many researchs it was found out that there is a negative relation between desired decision making styles and anxiety which lays in the basis of personality theories. While there is positive relation between maladaptive styles and anxiety (Fuqua, Newman \& Seaworth, 1998). Similarly, Kimes ve Troth (1974) stated there is a negative correlation between continuous anxiety and decisive manner. In a study on the 8th grade students carried out by Bacanlı \& Sürücü (2006) it was seen that students' decision making styles which are used to cope with making decision have an important role on the test anxiety. Also as other studies are investigated it can be seen that indecisive students generally are more anxious (Kuzgun, 1986), dependent, have low self-sufficiency compared to decisive students (Büyükgöze-Kavas, 2012).

However, there is no research that includes anxiety and indecisiveness at the same time or investigates the effect of psycho-education programs on indecisiveness for preventing test anxiety. In this context, this study is expected to make a contribution to the literature. 
Exams are processes that students must overcome during education-training process (Çapulcuoğlu, \& Gündüz, 2013). Therefore, there are many duties relate to school guidance services to help students become productive persons for the society (Adana \& Kaya, 2004; Erözkan, 2009; Totan \& Yavuz, 2009; Yıldırım, 2000). One of these duties is helping students through group guidance or setting up psycho-educational groups.

\section{Method}

\section{Research Design}

This research is a semi-experimental study that is carried out to decrease anxiety and indecisiveness of 8 th grade students with psycho-educational program for preventing test anxiety. The study is single group, based on pre-test, last-test model and was applied in sessions lasted 1-1. 5 hour a week and continued for 7 weeks.

\section{Study Group}

Survey was conducted during 2013 - 2014 academic year with 50 students who are in the learning process in a secondary school within Sur Central district in Diyarbakır. Test Anxiety Inventory (TAI) adapted to Turkish by Öner (1990) and Personal Indecisiveness Scale (PIS) developed by Bacanlı (2000) was applied to 8th grade students in order to determine students who will participate in the sessions. The study group was chosen according to points gained from these scales. 15 students whose anxiety and indecisiveness level is the highest were interviewed and given information about the aim of the study. The study was conducted with 5 girls and 5 boys 10 students in total who stated they were volunteer for the program. They all participated to all sessions except absence of two students in the termination session because of familial reasons.

\section{Data Collection Tools}

Test Anxiety Inventory and Personal Indecisiveness Scale were used in the study to collect data. Measurement tools were applied as pre-test last-test.

TAI is with 4 point Likert type inventory and consists of 20 items with subtests; "worry (12 items)" and "emotionality (8 items)". Points gained from TAl changes between $20-80$. TAI was developed by Spielberger and its Turkish translation, reliability and validity was tested by Öner (1990). High points gained from TAI means that test anxiety is also high.

PIS is with 5 point Likert type scale and consists of 18 items with two independent subscales; "investigator indecisiveness (10 items)" and "pushy indecisiveness ( 8 items). Points gained from PIS varies between $18-90$. Reliability and validity tests of PIS was done by Bacanlı (2000). High points gained from PIS shows that indecisiveness level is also high (Kuzgun \& Bacanlı, 2011).

\section{Process Path}

To determine participants, 10 volunteer students were chosen from 50 students whose anxiety level was the highest. Seven sessions were held lasting 1-1. 5 hours with each student from the group. Group guidance program which exists in the I. Volume of book named Experimantally Proved Psychological Counselling and Guidance Program that was printed for the third time by Pegem Akademi in 2012 and whose editors were Serdar Erkan and Alim Kaya was utilized.

Psycho-educaitonal program lasted seven session and it goes like this:

In the first session, participants of the group were introduced to each other, aims and rules of the group and expectations, feelings about the group were expressed, moreover basic information about test anxiety was given in order to make participants understand the relation between anxiety and success. In the second session, it was focused on perception of changes in body during or before exam, also focused on relaxation technique so that it was aimed participants to control their bodies during situations that make them anxious. In the third session, the aim for participants was using their their times according to their priorities and developing an understanding for this purpose so that they can prepare daily and weekly schedule for studying. In the fourth session, the focus was on comprehending developed methods with active listening as well as reading faster and more efficient. In the fifth session, the focus was on "ISOAT (Survey, Question, Read, Recite, Review)" technique aiming participants to comprehend methods for effective reading. In the sixth session, the focus 
was on grasping "Mental Regulation Technique" used for regulating irrational thinking manner in order to make students realize their irrational beliefs and change them with rational thoughts. In the seventh session, the aim was to make students comprehend "Exam Taking Skills" and focus on understanding "15 Attack Methods" to be successful in the exams, and then came the termination session.

\section{Analyzing Data}

In the beggining of the research, Wilcoxon Signed RanksTest was used to determine whether there is a meaningful difference between points gained from TAI and PIS pre-test last test measurements. In the interpretation of results . 05 meaning level was used as criteria.

\section{Findings and Interpretation}

In this chapter, there are statistical data analyse processes and results to put forward whether psycho-educational program for reducing test anxiety is effective on reducing test anxiety and personal indecisiveness levels of 8th grade students.

\section{Findings Related to Test Anxiety Inventory}

In Table 1 there is analyse of Wilcoxon Signed RanksTest for determining whether there is a meaningful difference of students test anxiety level according to pre-test last test points.

Table 1. findigs regarding the difference between pre-test last test points of students test anxiety .

\begin{tabular}{llllll}
\hline Tests & $\mathbf{N}$ & $\overline{\mathbf{X}}$ & Ss & $\mathbf{Z}$ & $\mathbf{p}$ \\
\hline Pre- Test & 8 & 57,12 & 8,49 & $-2,527$ &, 012 \\
\hline Last Test & 8 & 36,62 & 5,87 & & \\
\hline
\end{tabular}

When analyzing Table 1. , it can be seen that there is a meaningful difference between test anxiety points before and after the application $(z=-2.527, p<.05)$. Difference points being in favour of negative pairs (measurement in the beggining) shows that the program has a meaningful effect in reducing test anxiety.

\section{Findings Regarding Personal Indecisiveness Scale}

In Table 2. there is analyse of Wilcoxon Signed RanksTest for determining whether there is a meaningful difference of students personal indecisiveness level according to pre-test last test points.

Table 2. findings regarding difference between pre-test last test points of personal indecisiveness of students in Psychoeducational program.

\begin{tabular}{llllll}
\hline Tests & $\mathbf{N}$ & $\overline{\mathbf{X}}$ & Ss & $\mathbf{Z}$ & $\mathbf{p}$ \\
\hline Pre-Test & 8 & 54,00 & 10,16 & $-2,521$ &, 012 \\
\hline Last Test & 8 & 40,87 & 15,51 & & \\
\hline
\end{tabular}

When analyzing Table 2., it can be seen that there is a meaningful difference between personal indecisiveness points before and after the application $(z=-2.521, p<.05)$. Difference points being in favour of negative pairs (measurement in the beggining) shows that the program has a meaningful effect in reducing personal indecisiveness.

The main purpose of the study is testing the effect of psycho-educational program for reducing test anxiety and personal indecisiveness of participants. To determine realization of this aim, points of scale and inventory that was applied to the group were compared. Because, in both measurement tools, highness of points is undesired situation. Therefore, as 
Tables given above were investigated it can be mentioned that the program is effective on reducing test anxiety and personal indecisiveness.

\section{Conclusion, Arguement and Proposals}

In this chapter, findings regarding the effects of applied psycho-educational program for students' test anxiety and personal indecisiveness were argued and proposals were made in this context.

The first finding from the study shows that psycho-educational program has an effect on reducing test anxiety of students of the group. Yurdabakan (2012) in his study named The Effect of Group Guidance Program on 8th Grade Students' Test Anxiety Levels mentioned activities such as informing, relaxation exercises, exam taking skill, cognitive behavioral techniques, efficient studying skill and showed that group guidance program is effective on reducing test anxiety. Another study which is similar to this in terms of content and result was carried out by Erkan (1994). In this context it can be stated that this study has similar results to present studies.

Another finding from the study shows that psycho-educational program for reducing test anxiety has an effect on reducing personal indecisiveness of students of the group. Although, there is no study investigating effect of psycho-educational program for reducing test anxiety on personal in/decisiveness in the literature, there are few studies investigating relation between anxiety and decision makin styles / strategies. In the study of Bacanlı \& Sürücü (2006) on 8th grade secondary school students and study of Dereli \& Acat (2011) on students of Pre-School Teaching Department it was seen that decisin making skills can predict test anxiety. It can be understood vice versa with the present study.

Furthermore, it was observed that (both at the end of session and during termination phase "general evaluation of all sessions") secondary aims such as solving lackness of self expression, self confidence and social anxiety were affected by psycho-educational program. These secondary aims exist in "session diaries" which are given to students as homework during the process, and contain the summary of every session, and will stay with them. Öner (1990) stated that, students who has test anxiety are stressful, nervous and fearful not only during exams, but also during activities in the group like speaking, participating arguements, anwering questions, reading aloud. In this context, reduce in students test anxiety may lead to reduce in problems like lackness of self expression, self confidence, and social anxiety. Therefore, the statement of Öner (1990) support the indirect effect of psycho-educational program. Moreover, benefit of education and psycho-educational program to students were found out by other researchers (Çivitçi, 2005; Çolakkadıoğlu, 2010; Çolakkadıoğlu \& Güçray, 2012).

\section{Proceeding from these findings below proposals were made:}

1. This study showed that the psycho-educational program for prevention of test anxiety is effective on personal in/decisiveness. The effect of psycho-educational program for development of decision making skills might be investigated in a similar way.

2. As number of psychological counselors and number of students are considered a 10 sessioned program in which two variables are studied at the same time would be developed, instead of applying to each group test anxiety pyschoeducational program and decision making psycho-educational program differently. Hereby, it would be possible to save time and labor force and the number of students reached would increase.

3. This study was limited to 8th grade students. Other researchers can apply similar psycho-educational programs to different ages and wider sample groups.

4. Students are considered not to be neglecting their homeworks during psycho-educational program, and it is thought that this situation has increased efficiency gained from the group (depending on the result of pre-test last test). Researchers who will make similar studies are advised to use homeworks efficiently.

5. In this study absence of control group and absence of following process is a limitation. Therefore, it is possible to set up control group and do following process in order to increase effectivenes in other similar researches. 


\section{References}

[1] Adana, F. \& Kaya, N. (2004). Lise öğrencilerinin sınav kaygısı düzeyi üzerine sınav kaygısıyla başa çıkma eğitiminin etkisi, Kriz Dergisi 13 (2), 35-42

[2] Bacanlı, F. , \& Sürücü, M. (2006). İlköğretim 8. sınıf öğrencilerinin sınav kaygıları ve karar verme stilleri arasındaki ilişkilerin incelenmesi. Kuram ve Uygulamada Eğitim Yönetimi Dergisi, 12 (1), 7-35.

[3] Baltaş, A. , \& Baltaş, Z. (2002). Stres ve başaçıkma yolları. Remzi Kitabevi.

[4] Broman-Fulks, J. J. ,Berman, M. E. , Martin, H. M. , Marsic, A. \& Haris, J. A (2009). Phenomenon of declining anxiety sensitivity scores: A controlledinvestigation, Depression and Anxiety, 26, 1-9

[5] Büyükgöze-Kavas, A. (2012). Kariyer karar ölçeği'nin Türkçe uyarlaması: Geçerlik ve güvenirlik çalışması. Türk Psikolojik Danışma ve Rehberlik Dergisi,4 (38), 159-168.

[6] Carol, P. J. O \& Fisher, P. (2013). Metacognitions worry and attentional control in predicting OSCE performance test anxiety, Medical Education, 47, 562-568

[7] Çakır, M. A. (2004). Mesleki karar envanterinin geliştirilmesi. Ankara Üniversitesi Eğitim Bilimleri Dergisi, 37 (2), 1-14.

[8] Çapulcuoğlu, U. \& Gündüz, B. (2013). Öğrenci tükenmişliğini yordamada stresle başa çıkma sınav kaygısı akademik yetkinlik ve anne baba tutumları, Eğitim Bilimleri Araştırma Dergisi, 3 (1), 201-218

[9] Çivitci, A. (2005). Akılcı duygusal eğitimin ilköğretim öğrencilerinin mantık dışı inanç, sürekli kaygı ve mantıkı karar verme düzeylerine etkisi. Ege Eğitim Dergisi, 6, 59-80.

[10] Çolakkadıoğlu, O. (2010). Çatışma kuramına dayalı olarak geliştirilen karar verme beceri eğitimi grup uygulamalarının ergenlerin karar verme stillerine etkisi. Yayımlanmamış Doktora tezi, Çukurova Üniversitesi, Sosyal Bilimler Enstitüsü, Adana.

[11] Çolakkadıoğlu, O. , \& Güçray, S. S. (2012). Çatışma kuramına dayalı olarak geliştirilen karar verme beceri eğitimi psiko-eğitim grup yaşantısının ergenlerin karar verme stillerine etkisi. Kuram ve Uygulamada Eğitim Bilimleri Dergisi,12 (2), 655-676.

[12] Çolakkadioğlu, O. , \& Güçray, S. S. (2007). Ergenlerde karar verme ölçeğini Türkçe'ye uyarlama çalışması. Eurasian Journal of Educational Research (EJER), (26).

[13] Dereli, E. , \& Acat, M. B. (2011). Okulöncesi öğretmenliği bölümü öğrencilerinin karar verme stratejileri ile sınav kaygıları arasındaki ilişki. Eskişehir Osmangazi Üniversitesi Sosyal Bilimler Dergisi, 12 (2). 77 - 87

[14] Erkan, S. (2006). Rehberlik nedir. ,Y. Kuzgun (Ed). İçinde. Illköğretimde Rehberlik. Altıncı Baskı. Ankara: Nobel Yayınevi, ss. 1-16

[15] Erkan, Z. (1994). Grup rehberliği'nin yüksek sınav kaygısına etkisine yönelik deneysel bir çalışma. Yayımlanmamış Yüksek Lisans Tezi, Sosyal Bilimler Enstitüsü, Çukurova Üniversitesi, Adana.

[16] Erözkan, A. (2004). Üniversite öğrencilerinin sınav kaygısı ve başaçıkma davranışları. Sosyal Bilimler Ensitüsü Dergisi, 1 (12), 13 - 38

[17] Erözkan, A. (2009). İlköğretim sekizinci sınıf öğrencilerinde depresyonun yordayıcıları, Elementary Education Online, 8 (2), 334-345

[18] Ertürk, S. (1986). Eğitimde program geliştirme. Ankara: Yelkentepe Yayınları.

[19] Fidan, N. (2012). Okulda öğrenme ve öğretme. PegemAkademi Yayınları

[20] Fuqua, D. R. , Newman, J. L. , \& Seaworth, T. B. (1988). Relation of state and trait anxiety to different components of career indecision. Journal of Counseling Psychology, 35 (2), 154. 
[21] Grzesiak-Feldman, M. (2013). The effect high-anxiety situation on conspiracy thinking, Current Psychology, $32,100-118$

[22] Kimes, H. G. , \& Troth, W. A. (1974). Relationship of trait anxiety to career decisiveness. Journal of Counseling Psychology, 21 (4), 277.

[23] Kuzgun, Y. \& Bacanlı, F. (2011). Rehberlik \& Psikolojik Danışmada Kullanılan Ölçekler (3. Baskı). Ankara: Nobel yayın dağıtım

[24] Kuzgun, Y. (1986). Meslek seçiminde kararsızlık. Ankara Üniversitesi Eğitim Fakültesi Dergisi, 217-223

[25] Lowe, P. A. , Lee, S. W. , Witteborg, K. M. , Prichard, K. W. , Luhr, M. E. , Cullinan, C. M. , . . \& Janik, M. (2008). The test anxiety inventory for children and adolescents (TAICA) examination of the psychometric properties of a new multidimensional measure of test anxiety among elementary and secondary school students. Journal of Psychoeducational Assessment, 26 (3), 215-230.

[26] Meijer, J. (2001). Learning potential and anxious tendency: Test anxiety as a bias factor in educational testing. Anxiety, stress and Coping, 14 (3), 337-362.

[27] Öner, N. (1990). Sınav Kaygısı Envanteri El Kitabı. İstanbul: Yöret Yayınları.

[28] Piji Küçük, D. (2010). Müzik öğretmeni adaylarının sınav kaygısı benlik saygısı ve çalgı başarıları arasındaki ilişkinin incelenmesi, Ahi Evran Üniversitesi Eğitim Fakültesi Dergisi, 11 (3), 37-50

[29] Senemoğlu, N. (2009). Gelişim Öğrenme ve Öğretim Kuramdan Uygulamaya (15. Baskı). Ankara: Pegem A yayıncillk

[30] Sönmez, V. (1987). Eğitim ortamında sevgi. Hacettepe Üniversitesi Eğitim Fakültesi Dergisi, 2 (2). 65 - 77

[31] Sparfeldt, J. R. ,Rost, D. H. , Baumestier, U. M. \& Christ, O. (2013). Test anxiety in written and oral examinations, Learning And Individual Differences, 24, 198-203

[32] Şahin, A. E. (2007). Eğitimle ilgili temel kavramlar. ,V. Sönmez (Ed). İçinde. Eğitim Bilimine Giriş. Üçüncü Baskı. Ankara: Anı Yayıncılık, ss. 1-24

[33] Şahin, H. , Günay, T. \& Batı, H. (2006). İzmir Illi Bornova İlçesi Lise Son Sınıf Öğrencilerinde Üniversiteye Giriş Sınavı Kaygısı. Sted 15 (6), 107-113

[34] Totan, T. \& Yavuz, Y (2009). Westside sınav kaygısı ölçeğinin Türkçe formunun geçerlik ve güvenirlik çalışması, Mehmet Akif Ersoy Üniversitesi Eğitim Fakültesi Dergisi, 9 (17), 95-109

[35] Yıldırım, İ. (2000). Akademik başarının yordayıcısı olarak yalnızık sınav kaygısı ve sosyal destek, Hacettepe Üniversitesi Eğitim Fakültesi Dergisi 18, 167 - 176

[36] Yöndem, Z. D. (2011). Kişilik Dinamikleri ve Stresle Baş etme (2. Baskı). Ankara: Efil yayınevi

[37] Yurdabakan, İ. (2012). Grup rehberliği programının ilköğretim sekizinci sınıf öğrencilerinin sınav kaygısı düzeylerine etkisi. S. Erkan, \& A. Kaya, (Ed. ) içinde. Deneysel olarak sınanmış Grupla Psikolojik Danışma ve Rehberlik Programları I. Cilt, Üçüncü Baskı. Ankara: PegemAkademi yayınları 